\title{
Multi-decadal marine- and land-terminating glacier recession in the Ammassalik region, southeast Greenland
}

\author{
S. H. Mernild ${ }^{1}$, J. K. Malmros ${ }^{2}$, J. C. Yde ${ }^{3}$, and N. T. Knudsen ${ }^{4}$ \\ ${ }^{1}$ Climate, Ocean, and Sea Ice Modeling Group, Los Alamos National Laboratory, New Mexico, USA \\ ${ }^{2}$ Department of Geography and Geology, University of Copenhagen, Denmark \\ ${ }^{3}$ Sogn og Fjordane University College, Sogndal, Norway \\ ${ }^{4}$ Department of Geoscience, Aarhus University, Aarhus, Denmark \\ Correspondence to: S. H. Mernild (mernild@lanl.gov)
}

Received: 26 January 2012 - Published in The Cryosphere Discuss.: 7 February 2012

Revised: 9 May 2012 - Accepted: 15 May 2012 - Published: 6 June 2012

\begin{abstract}
Landsat imagery was applied to elucidate glacier fluctuations of land- and marine-terminating outlet glaciers from the Greenland Ice Sheet (GrIS) and local landterminating glaciers and ice caps (GIC) peripheral to the GrIS in the Ammassalik region, Southeast Greenland, during the period 1972-2011. Data from 21 marine-terminating glaciers (including the glaciers Helheim, Midgaard, and Fenris), the GrIS land-terminating margin, and 35 GIC were examined and compared to observed atmospheric air temperatures, precipitation, and reconstructed ocean water temperatures (at $400 \mathrm{~m}$ depth in the Irminger Sea). Here, we document that net glacier recession has occurred since 1972 in the Ammassalik region for all glacier types and sizes, except for three GIC. The land-terminating GrIS and GIC reflect lower marginal and areal changes than the marine-terminating outlet glaciers. The mean annual land-terminating GrIS and GIC margin recessions were about three to five times lower than the GrIS marine-terminating recession. The marineterminating outlet glaciers had an average net frontal retreat for 1999-2011 of $0.098 \mathrm{~km} \mathrm{yr}^{-1}$, which was significantly higher than in previous sub-periods 1972-1986 and 19861999. For the marine-terminating GrIS, the annual areal recession rate has been decreasing since 1972, while increasing for the land-terminating GrIS since 1986. On average for all the observed GIC, a mean net frontal retreat for 19862011 of $0.010 \pm 0.006 \mathrm{~km} \mathrm{yr}^{-1}$ and a mean areal recession of around $1 \%$ per year occurred; overall for all observed GIC, a mean recession rate of $27 \pm 24 \%$ occurred based on the 1986 GIC area. Since 1986, five GIC melted away in the Ammassalik area.
\end{abstract}

\section{Introduction}

The Greenland Ice Sheet (GrIS) - land- and marineterminating outlet glaciers on the periphery of the GrIS - and local land-terminating glaciers and ice caps (GIC) peripheral to the GrIS have undergone rapid changes over the last decades. Most notable changes are thinning, leading to destabilization and accelerated retreat of GrIS marine-terminating glaciers (Joughin et al., 2004, 2010; Howat et al., 2005, 2008; Rignot and Kanagaratnam, 2006; Moon and Joughin, 2008; Nick et al., 2009), and increasing mass loss, thinning, and retreat of land-terminating GIC (Yde and Knudsen, 2007; Mernild et al., 2011a; Radić and Hock, 2011).

The underlying mechanisms of GrIS marine-terminating glacier dynamics remain somehow unclear (Straneo et al., 2010; Johannessen et al., 2011). The frontal recessions at the calving front are highly due to changes in the force balance due to thinning, reduced resistive force, and speed-up based on warming of oceanic subsurface waters and warming of the atmosphere, where warm subsurface waters are suggested by Luthcke et al. (2006), Velicogna and Wahr (2006), Holland et al. (2008), Howat et al. (2008), Thomas et al. (2009), van den Broeke et al. (2009), Velicogna (2009), Murray et al. (2010), Rignot et al. (2010), Straneo et al. (2010), and Andresen et al. (2011) to play a significant role. However, Johannessen et al. (2011) stated, based on statistical correlations, that penetration of snow and ice melt water to the glacier bed might play an important role, influencing the GrIS sliding and dynamic processes. The mechanisms suggested for land-terminating GIC recession are less complex. In the Ammassalik region, Southeast Greenland, studies of GIC have shown that mass loss and margin retreat have 


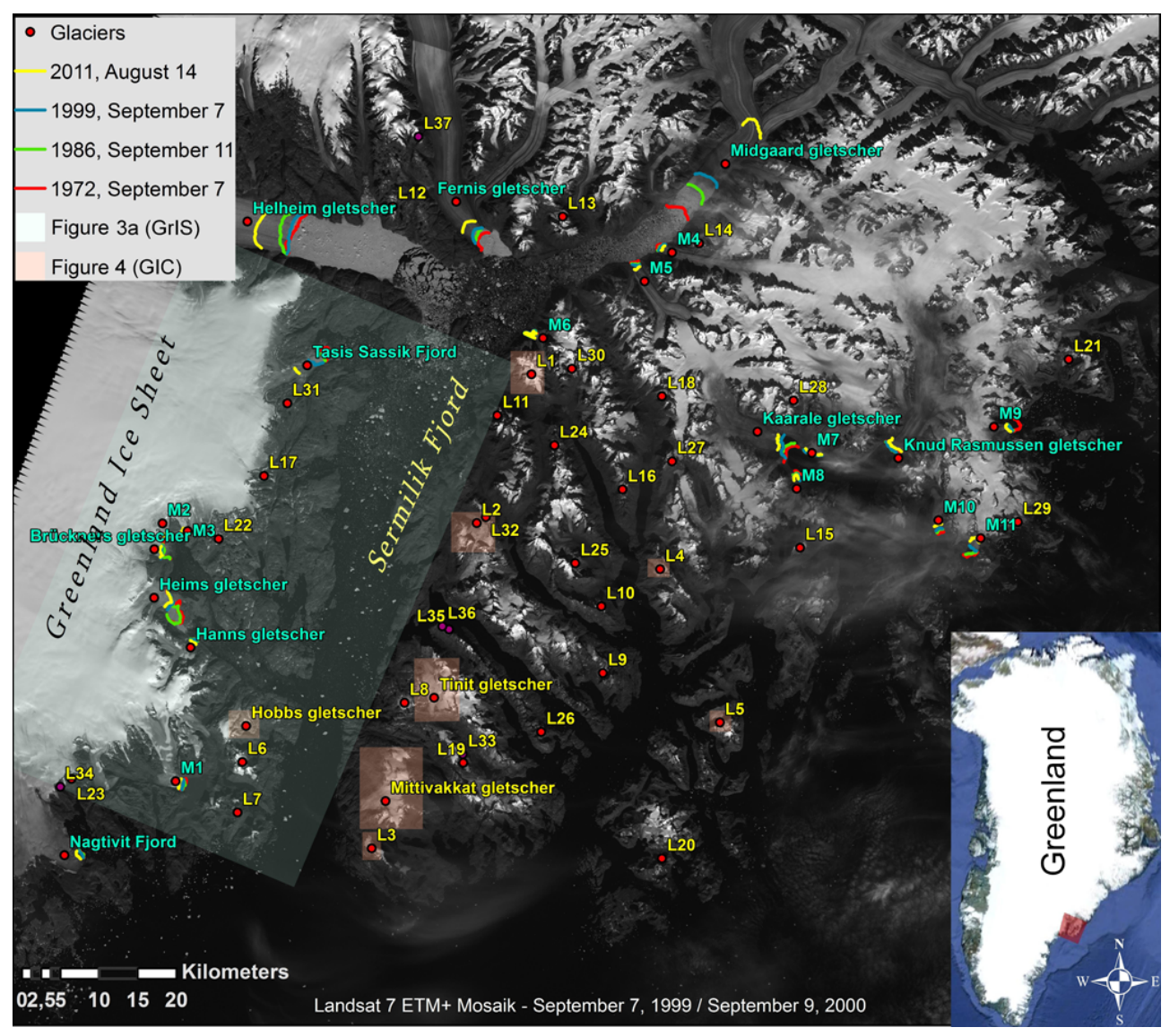

Fig. 1. The Ammassalik region, including the Sermilik Fjord and parts of the southeastern sector of the GrIS. The marine-terminating glacier margins are marked with positions (lines) for each of the survey years: 1972 (red color), 1986 (green), 1999 (blue), and 2011 (yellow) (the location names are written in turquoise). The 35 local land-terminating glaciers and ice caps (GIC) peripheral to the GrIS are written in yellow, where eight are marked with shaded areas; marginal changes for those eight GIC and the GrIS are illustrated in detail. The GIC marked with L33-L37 are examples of GIC that melted away during 1986-2011. The inset figure indicates the general location of the Ammassalik region in Southeast Greenland (source: Landsat 7 ETM+ Mosaik, 7 September 1999/9 September 2000).

been driven mainly by higher surface temperatures (increasing surface ablation) and decreasing precipitation (decreasing snow accumulation) since the mid-1900s (Mernild et al., 2011a).

The glacier contribution to sea-level rise from Greenland marine-terminating glaciers has been analyzed by satellite. Howat and Eddy (2011) identified changes in ice-frontal positions from 210 GrIS marine-terminating glaciers with fronts wider than $1 \mathrm{~km}$ (spanning nearly four decades, 19722010). These results show a trend of accelerated recession, where $90 \%$ of the observed glaciers receded between 2000 and 2010. Box and Decker (2011) identified areal changes at 39 of the widest Greenland marine-terminating glaciers (2000-2010). Collectively, the 39 glaciers lost a cumulative area of $1368 \mathrm{~km}^{2}$. For the Ammassalik region - a region including the Ammassalik Island, the Sermilik Fjord (the largest fjord system in Southeast Greenland) and its surrounding landscape - only frontal changes of major GrIS marine-terminating glaciers, such as Helheim, Fenris, and
Midgaard glaciers, have been observed in earlier studies; however, at least 21 marine-terminating glaciers have been identified; all 21 were included in this study (Fig. 1).

For the land-terminating GIC in Greenland, margin retreat has been sparsely observed (Yde and Knudsen, 2007), and the only currently published time series of whole glacier insitu mass balance observations (since 1995/1996) is from the Mittivakkat Gletscher, located in the Ammassalik region (WGMS, 2009; Mernild et al., 2011a), even though thousands of individual GIC are located on the land-strip between the GrIS and ocean, of which several hundred are situated in the Ammassalik region (Mernild et al., 2012). Thus, there is a need for more information about contemporary glacier fluctuations of Greenlandic GIC and their coupling to climate change.

The ability to assess GrIS and GIC margin changes in the Ammassalik region has been improved through the use of Landsat imagery dating back to 1972 . The imagery gives us the possibility to map "snapshots" and the averaged 
Table 1. Satellite platform, sensors, band information, scenes used in the analysis, and uncertainties related to the satellite classification process.

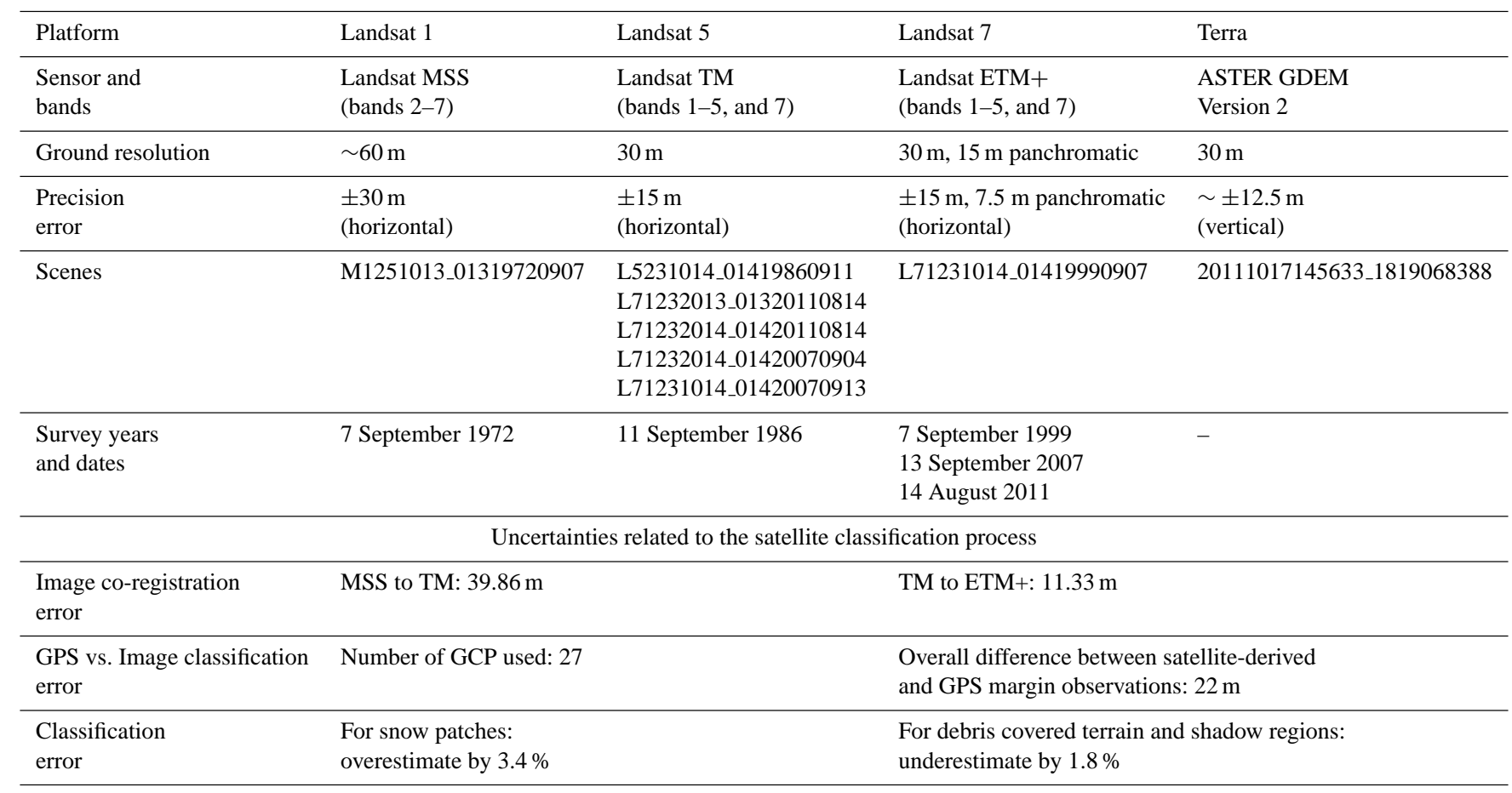

behaviour of glacier changes for the past four decades for the identified marine-terminating glaciers, the GrIS landterminating margin, and the GIC during a period of climate warming. The average multi-decadal glacier recession in the Ammassalik region $\left(65^{\circ} \mathrm{N}, 37^{\circ} \mathrm{W}\right)$ was examined, rather than the annual range of variability, even though recent observations suggest that major changes in the dynamics of Greenland marine-terminating glaciers take place over timescales of 3-10 yr (Howat et al., 2007; Nick et al., 2009; Andresen et al., 2011; Johannessen et al., 2011), rather than over several decades or centuries as previously believed (Truffer and Fahnestock, 2007).

Here, on approximately decadal scale we examine net frontal position and area fluctuations using multispectral Landsat satellite data, observing 21 marine-terminating glaciers from 1972-2011, land-terminating glacier frontal positions for parts of the GrIS, and of 35 GIC from 19862011 for the Ammassalik region - a region including the thermodynamic transition zone from the North Atlantic Ocean into the Arctic Ocean through the Denmark Strait. Changes were considered in the context of meteorological observations and reconstructed ocean water temperature time series. As part of the study, the cumulative net area changes for the marine-terminating glaciers were examined. Finally, we investigate differences in marginal change rates between the marine and the terrestrial glacier environments.

\section{Data and methods}

The Landsat and Advanced Spaceborne Thermal and Reflection Radiometer (ASTER) Global Digital Elevation Model Version 2 (GDEM v2) scenes were selected and acquired through WIST (http://reverb.echo.nasa.gov/reverb/redirect/ wist: EOSDIS, 2009): Landsat 1 carried the four-band Multispectral Scanner (MSS); Landsat 5 carried the seven-band Thematic Mapper (TM); and Landsat 7 carried the eightband Enhanced Thematic Mapper Plus (ETM+), having a ground resolution of $\sim 60,30$, and $30 \mathrm{~m}$ ( $15 \mathrm{~m}$ in the panchromatic band 8), respectively. The ASTER GDEM v2 provides a ground resolution of $30 \mathrm{~m}$ (Table 1) and is used to estimate minimum, mean, and maximum GIC elevations.

Data were obtained from seven relatively cloud-free scenes ( $>25 \%$ cloud free) covering the Ammassalik region at the end of the ablation period (mid-August through midSeptember) for the time series analysis (i.e., 1972, 1986, 1999, 2007, and 2011, Table 1). For 1972 the GrIS and GIC land-terminating margin analyses were omitted due to difficulties in separating ice cover from snow cover; the year 1972 was one of the coldest years during the study period, and the year with the lowest satellite-derived melt extent cover for GrIS (Mernild et al., 2011b). For 2011, scenes from 2007 were used for filling gaps, due to the ETM+ sensor Scan Line Instrument (SLI) malfunction. Because of the four year gap between 2007 and 2011, the gapfilled procedure was used only when absolutely necessary to 


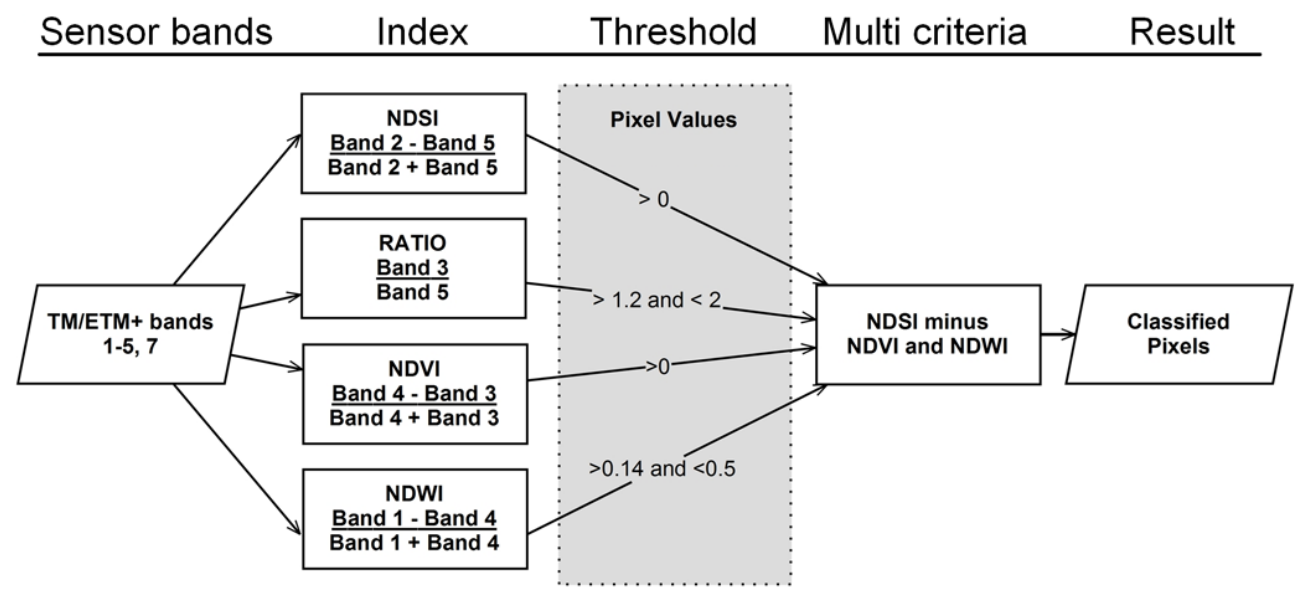

Fig. 2. An example of the multi-criteria analysis for the Landsat $5 \mathrm{TM}$ and Landsat $7 \mathrm{ETM}+$ scenes. For the latter the corresponding values were $1999 \mathrm{NDSI}>0$, NDWI $>0.16$ and $<0.45$, and NDVI $<0$, and for $2011 \mathrm{NDSI}>0$, NDWI $>0.15$ and $<0.5$, and NDVI $<0$. Band ratios were the same for all scenes. The analysis was carried out using the tool BandMath in ENVI ${ }^{\mathrm{TM}}$.

minimize misclassification. All imagery and features were projected in WGS84, UTM Zone $24 \mathrm{~N}$, and the selected scenes were radiometricly calibrated using the Landsat calibration tool in ENVI ${ }^{\mathrm{TM}}$ software package (http://www.ittvis. com/ProductServices/ENVI.aspx), converting the band values to "At Surface Reflectance". The individual bands (TM and ETM+ bands 1-5, and 7, and MSS bands 2-7) were standardized using the ENVI ${ }^{\mathrm{TM}}$ Dark Subtract (DS) tool before ratio and indices were calculated. Standard pixel errors associated with the different scenes and sensors were $\pm 30 \mathrm{~m}$ (MSS), $\pm 15 \mathrm{~m}$ (TM), $\pm 15 \mathrm{~m}$ (7.5 m panchromatic) (ETM+), and $\pm 30 \mathrm{~m}$ (ASTER GDEM v2). The error associated with the ASTER GDEM v2 is expected to be $\sim \pm 12.9 \mathrm{~m}$ vertically (Table 1); however, larger uncertainty might occur vertically in steep terrain and in areas of poor contrasts (Tachikawa et al., 2011).

The image co-registration errors associated with the individual sensor types were $39.86 \mathrm{~m}$ (MSS-TM) and $11.33 \mathrm{~m}$ (TM-ETM+) (due to the root mean square, RMS), based on 27 near-sea ground control points (GCP) for each sensor type (Table 1). The supervised classification process used for the 1986, 1999, and 2011 scenes was based on a multi-criteria analysis involving the calculation of a set of indices (Fig. 2): normalized difference snow index (NDSI; Dozier and Warren, 1982); normalized difference water index (NDWI; Gao, 1996); NDVI (normalized difference vegetation index; Rouse et al., 1973); and RATIO bands 3/5 $\mathrm{TM} / \mathrm{ETM}+$. The RATIO was used in reference due to better performance than the NDSI index in mountainous areas (like the Ammassalik region) capturing ice and snow covered areas influenced by shadows and debris (Paul, 2004). The NDVI was used to filter out vegetation and the NDWI to identify and filter out lakes in the margin area of the GrIS and GIC. The resulting classifications were converted to (1) polygon files and cleaned up manually in ESRI ${ }^{\mathrm{TM}}$ ArcMap by visual inspection, (2) poly-line files for visual presentation; and (3) point shapes with a 30-m distribution along the lines and used to examine the mean and median center of the margin distribution for each year. The 1972 scene was not included in the classification process since the spectral bands of the Landsat 1 MSS sensor used different wavelengths and band distribution than both the TM and ETM+ sensors, and thus is not eligible for this type of snow/ice classification. The raw model precision errors for each year compared with the cleaned up classification were found to be $5.2 \%$ (overestimate by $3.4 \%$ due to snow patches and underestimate by $1.8 \%$ due to heavily debris covered terrain and shadow regions) overall, with 1999 being the most troublesome year (Table 1).

The GrIS and GIC margin positions were digitized for each of the years, and the distance between the margins was calculated at the dominant glacier's flow direction using a centerline method approach. The expected errors related to the classification and determination of the glacier margin positions are shown in Table 1.

The selection of the 35 GIC was randomly chosen: (1) following the regional distribution due to size, aspect, and elevation, and (2) trying to avoid area where the 2011 scene SLI failure could influence the classification. The 2007 scene gap-fill was used in reference only when absolutely necessary.

The Landsat-derived 2011 (14 August) GIC margin was validated for the Mittivakkat Gletscher against the 2011 (9 August) GPS-observed margin; only the lower elevated margin of the Mittivakkat Gletscher was observed. The location of the observed margin was obtained from portable single-frequency GPS measurements having a relative uncertainty of about $\pm 5 \mathrm{~m}$ (Mernild et al., 2011a). Overall, the RMS difference between the 2011 satellite and GPS margin observations was $22 \mathrm{~m}$ (Fig. 3 and Table 1). 


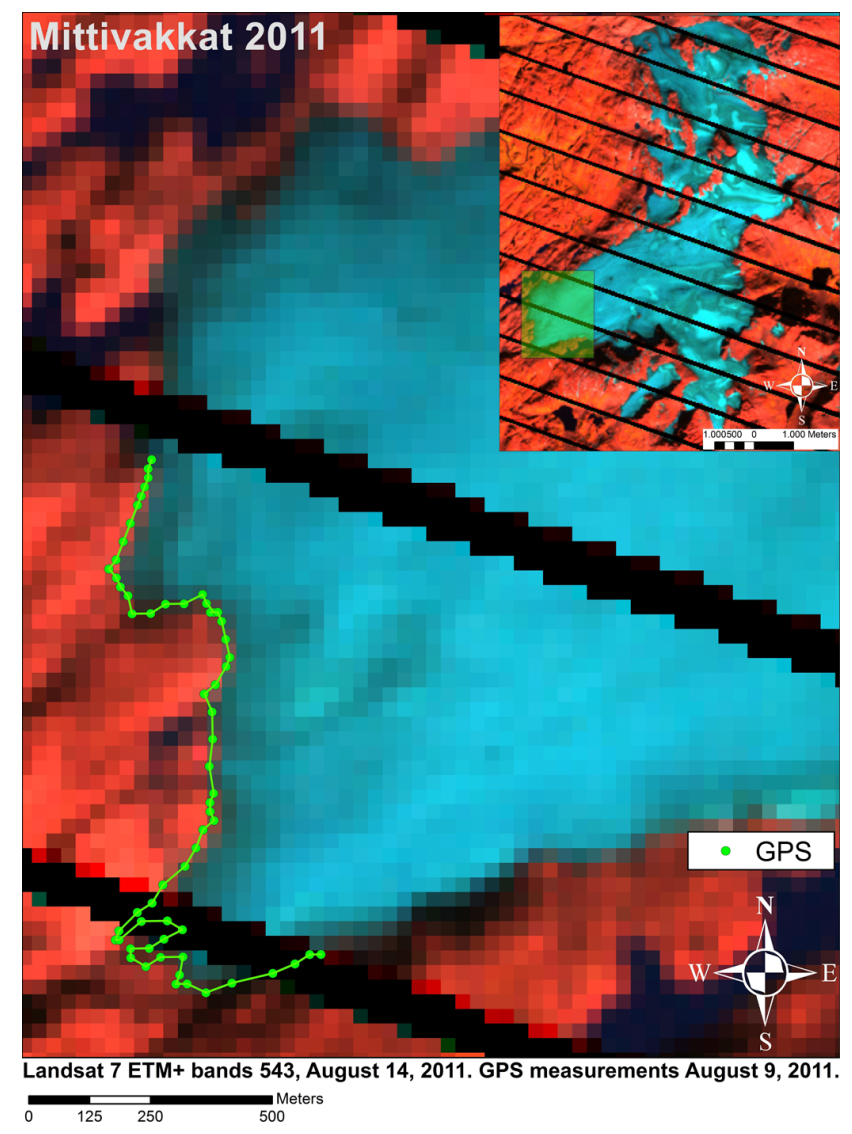

Fig. 3. A comparison between the Landsat-derived Mittivakkat Gletscher margin and the observed margin based on portable GPS observations (green line with dots) for August 2011. The inset figure indicates the location of the observed margin at Mittivakkat Gletscher. The oblique black lines are due to the SLI malfunction.

The observed meteorological data, air temperature and precipitation were obtained from the Danish Meteorological Institute (DMI) station in Tasiilaq for 1972-2011, located less than $10 \mathrm{~km}$ from the Sermilik Fjord outlet, and reconstructed ocean subsurface water temperatures at $400 \mathrm{~m}$ depth in the Irminger Sea were used as a proxy for the variability of the subsurface warm Atlantic water in the Sermilik Fjord (Johannessen et al., 2011).

\section{Results and discussion}

\subsection{Marine-terminating glaciers}

For the Ammassalik region, the 21 observed marineterminating glaciers, on average for the survey period 1972 2011 , receded at a net rate of $0.053 \pm 0.113 \mathrm{~km} \mathrm{yr}^{-1}$ (here and below, the \pm standard deviations are included) with a median of $0.025 \mathrm{~km} \mathrm{yr}^{-1}$ (Table 2). For 1999-2011, the mean net recession rate was $0.098 \pm 0.171 \mathrm{~km} \mathrm{yr}^{-1}$, which is in accordance with the mean net recession rate of $0.11 \mathrm{~km} \mathrm{yr}^{-1}$ for 210 GrIS marine-terminating outlet glaciers (2000-2010) determined by Howat and Eddy (2011). For the sub-periods the fraction of marine-terminating glaciers in net recession increased from $57 \%$ (1972-1986), 86\% (1986-1999) to $100 \%$ (1999-2011), indicating complete marine-terminating glacier retreat for the Ammassalik region since 1999. For Southeast Greenland, Howat and Eddy (2011) estimated an increasing fraction of net retreat from $55 \%$ (1972-1985), $73 \%(1985-2000)$ to $89 \%(2000-2010)(n=38)$. For the last period, this was almost in the same order of magnitude as the fraction of glacier recession determined for the Ammassalik region.

On an individual glacier scale, Midgaard, Helheim, Tasis Sassik Fjord, Heims, and Fenris had (as listed) the five highest net recession rates of $0.365 \mathrm{~km} \mathrm{yr}^{-1}$ (this equals a net frontal recession of $14.3 \mathrm{~km}), 0.155 \mathrm{~km} \mathrm{yr}^{-1}$ $(6.0 \mathrm{~km}), 0.130 \mathrm{~km} \mathrm{yr}^{-1}(5.1 \mathrm{~km}), 0.075 \mathrm{~km} \mathrm{yr}^{-1}(2.8 \mathrm{~km})$, and $0.065 \mathrm{~km} \mathrm{yr}^{-1}(2.6 \mathrm{~km})$, respectively (Fig. 4) for $1972-$ 2011. All five glaciers are outlets from the GrIS, receiving ice from the interior of the ice sheet, having the largest GrIS catchment areas within the Ammassalik region and probably also the greatest ice thickness and therefore more susceptible to enhanced submarine melting via warmer water intruding beneath the ice, than the other observed outlet glaciers (due to their shallow depth of the glacier bases). Overall for the Ammassalik region, $80 \%$ of the marine-terminating glaciers receded at rates less than $0.050 \mathrm{~km} \mathrm{yr}^{-1}$ (Fig. 4), and Thomas et al. (2009) suggested that outlet glaciers without deep beds are changing far more slowly. The mean net recession rates during the period 1972-2011 for the glaciers Midgaard, Helheim, and Fenris compared well with the recession rates determined by Howat and Eddy (2011) for 1972-2010.

For the sub-periods, the 21 observed marine-terminating glaciers had mean frontal recession rates of $0.031 \pm 0.056$ and $0.029 \pm 0.060 \mathrm{~km} \mathrm{yr}^{-1}$ for 1972-1986 and 19861999, respectively (significantly similar, $97.5 \%$ quartile). For 1999-2011, the mean recession rate increased to $0.098 \pm 0.171 \mathrm{~km} \mathrm{yr}^{-1}$, which was significantly higher $(95 \%$ quartile) than the two previous sub-periods, and about 3.2 times higher than the 1972-1986 rate. The same trend occurred for the median recession rates, where the 19992011 rate was 5.4 times higher than for 1972-1986 (Table 2). The high mean rates for 1999-2011 were mainly due to the recession at the glaciers Midgaard, Helheim, F5, and Fenris, whereas both Midgaard Gletscher and Helheim Gletscher were outside the $75 \%$ percentiles (Fig. 5a). Also, for 1972-1986 and 1986-1999 Midgaard Gletscher and Helheim Gletscher were considered as outliers. The maximum net advance rate in the dataset was observed for Helheim Gletscher of $0.100 \mathrm{~km} \mathrm{yr}^{-1}$ (1986-1999). A maximum net recession rate was observed for Midgaard Gletscher of $0.700 \mathrm{~km} \mathrm{yr}^{-1}$ (1999-2011) (Figs. 1 and 5a). For the Ammassalik region in general, the mean recession rate has increased since 1972 (Fig. 5a). Howat and Eddy (2011), for the GrIS outlet glaciers, noted a transition from stable and 
Table 2. Frontal position change rate statistics for the period 1972-2011 for the GrIS marine-terminating glaciers in the Ammassalik region, mean annual air temperature and precipitation anomaly from the DMI meteorological station in Tasiilaq, and mean annual reconstructed ocean water temperature anomaly at $400 \mathrm{~m}$ depth in the Irminger Sea (Johannessen et al., 2011).

\begin{tabular}{|c|c|c|c|c|c|c|c|c|c|}
\hline Range & $\begin{array}{l}\text { Number of } \\
\text { GrIS } \\
\text { marine- } \\
\text { terminating } \\
\text { glaciers }\end{array}$ & $\begin{array}{l}\text { Mean annual } \\
\text { air tempera- } \\
\text { ture anomaly } \\
\text { and standard } \\
\text { deviation } \\
\left({ }^{\circ} \mathrm{C} \mathrm{yr}^{-1}\right)\end{array}$ & $\begin{array}{l}\text { Mean annual } \\
\text { precipitation } \\
\text { anomaly } \\
\text { and standard } \\
\text { deviation } \\
\text { (mm w.e. } \mathrm{yr}^{-1} \text { ) }\end{array}$ & $\begin{array}{l}\text { Mean annual } \\
\text { reconstructed } \\
\text { ocean water } \\
\text { temperature } \\
\text { anomaly } \\
\text { and standard } \\
\text { deviation } \\
\left({ }^{\circ} \mathrm{C} \mathrm{yr}^{-1}\right)\end{array}$ & $\begin{array}{l}\text { Glacier } \\
\text { fraction in } \\
\text { net retreat } \\
(\%)\end{array}$ & $\begin{array}{l}\text { Mean change } \\
\text { rate and } \\
\text { standard } \\
\text { deviation } \\
\left(\mathrm{km} \mathrm{yr}^{-1}\right)\end{array}$ & $\begin{array}{l}\text { Median } \\
\text { change rate } \\
\left(\mathrm{km} \mathrm{yr}^{-1}\right)\end{array}$ & $\begin{array}{l}\text { Maximum } \\
\text { advance rate } \\
\left(\mathrm{km} \mathrm{yr}^{-1}\right)\end{array}$ & $\begin{array}{l}\text { Maximum } \\
\text { recession rate } \\
\left(\mathrm{km} \mathrm{yr}^{-1}\right)\end{array}$ \\
\hline $\begin{array}{l}1972- \\
1986\end{array}$ & 21 & $-0.63 \pm 0.78$ & $69 \pm 212$ & $-0.12 \pm 0.30$ & 57 & $-0.031 \pm 0.056$ & -0.007 & 0.005 & -0.223 \\
\hline $\begin{array}{l}1986- \\
1999\end{array}$ & 21 & $-0.33 \pm 0.63$ & $-17 \pm 238$ & $-0.06 \pm 0.49$ & 86 & $-0.029 \pm 0.060$ & -0.009 & 0.100 & -0.187 \\
\hline $\begin{array}{l}1999- \\
2011\end{array}$ & 21 & $1.08 \pm 0.59$ & $-62 \pm 163$ & $0.23 \pm 0.43^{*}$ & 100 & $-0.098 \pm 0.171$ & -0.038 & -0.003 & -0.758 \\
\hline $\begin{array}{l}1972- \\
2011\end{array}$ & 21 & - & - & - & 100 & $-0.053 \pm 0.113$ & -0.025 & 0.100 & -0.758 \\
\hline
\end{tabular}

* Data are missing from 1995 and 1996, and only present until 2009.

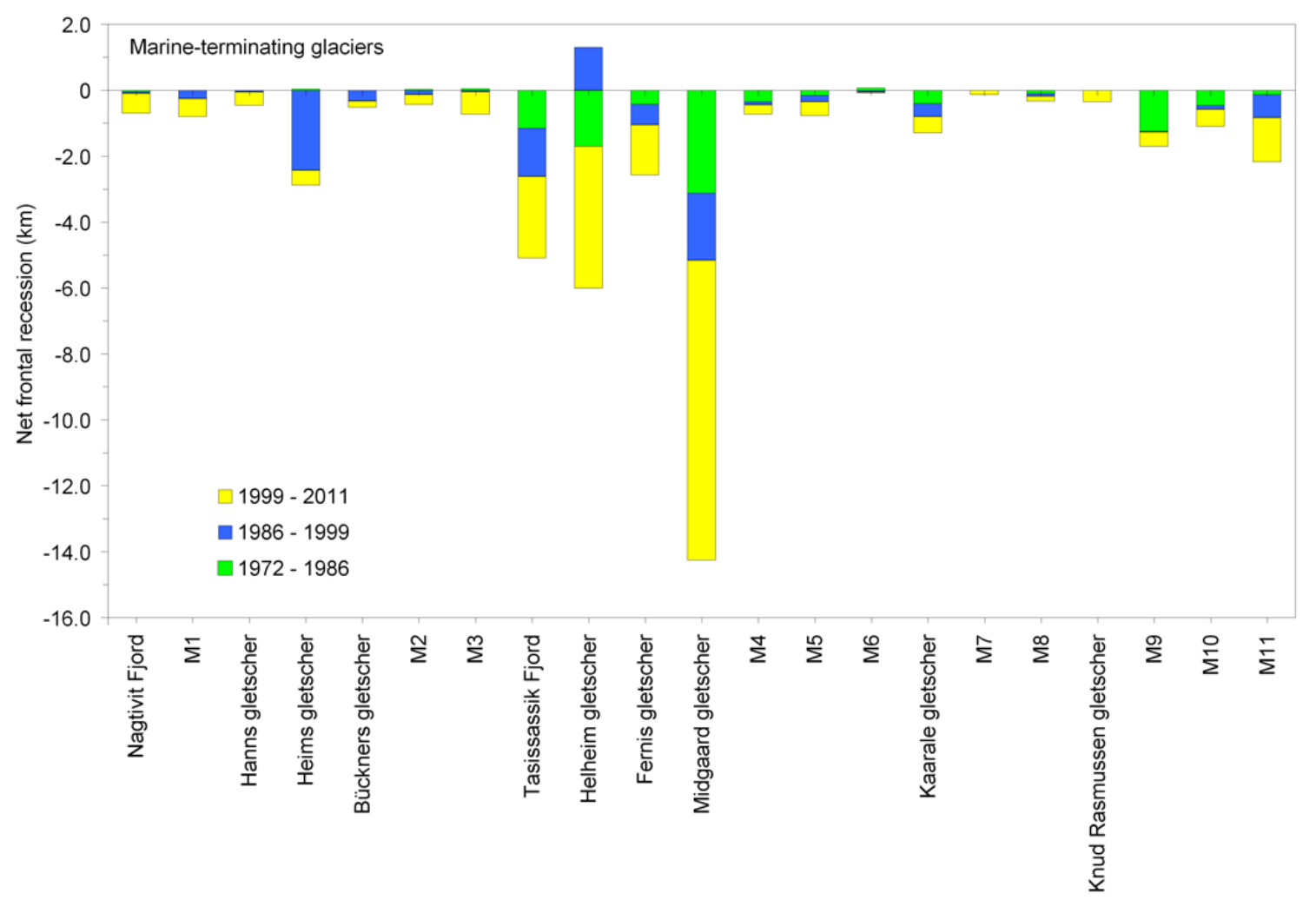

Fig. 4. Satellite-derived net frontal recession for the 21 marine-terminating glaciers in the Ammassalik region for the sub-periods $1972-1986$ (green), 1986-1999 (blue), and 1999-2011 (yellow). For glacier locations, see Fig. 1.

small fluctuations in glacier frontal positions (1972-1985) to moderately widespread recession in the southeast and western parts of GrIS (1985-2000), followed by an accelerated net recession in all regions of the ice sheet (2000-2010).

Since 1972, the 21 marine-terminating glaciers showed a cumulative net area loss of $281 \mathrm{~km}^{2}$, with mean annual area loss rates of $7.2 \mathrm{~km}^{2} \mathrm{yr}^{-1}$ (Fig. 6). The largest individual marine-terminating area loss occurred at Midgaard Gletscher of $130 \mathrm{~km}^{2}$ (equal to $46 \%$ of the cumulative net area exposure in the Ammassalik region), followed by Helheim Gletscher of $67 \mathrm{~km}^{2}$ (equal to $24 \%$ ). About $70 \%$ of the glaciers had an area loss less than 


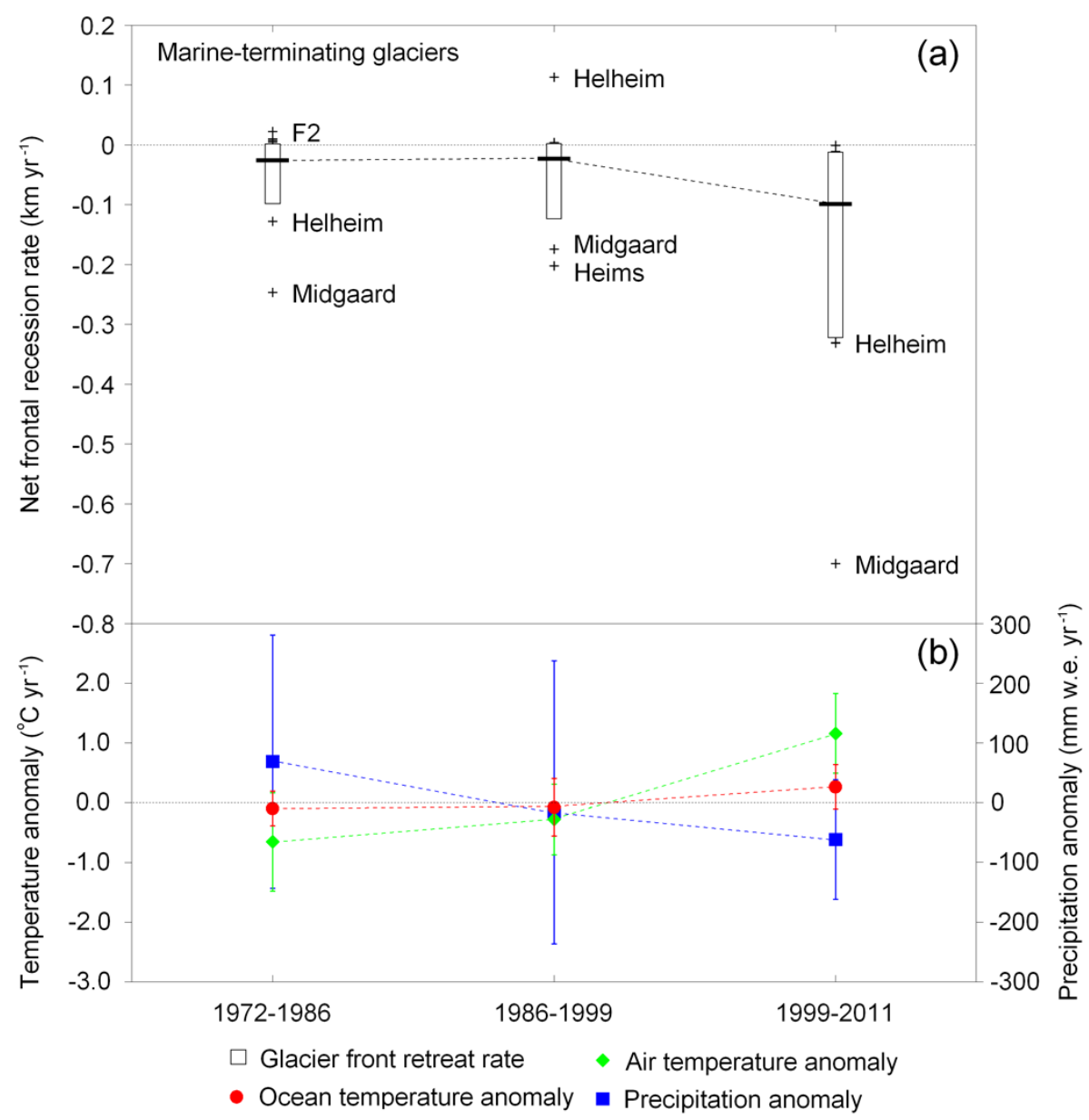

Fig. 5. (a) Box plots of frontal-position change for the sample 21 marine-terminating glaciers in the Ammassalik region with measurements in each of the 1972-1986, 1986-1999, and 1999-2011 survey periods. The edges of the boxes denote $25 \%$ and $75 \%$ percentiles and the vertical line mean. Data points outside this range are considered outliers and are plotted as crosses and labeled; (b) mean annual air temperature anomaly (observed at the DMI meteorological station in Tasiilaq), mean annual ocean water temperature anomaly at $400 \mathrm{~m}$ depth in the Irminger Sea (Johannessen et al., 2011), mean annual precipitation anomaly (uncorrected) (observed at the DMI meteorological station in Tasiilaq) and standard deviations are shown.

$4 \mathrm{~km}^{2}$ during the period 1972-2011. Also, the $21 \mathrm{ob}-$ served marine-terminating glaciers had a trend towards lower annual area loss rates (Fig. 6): for the subperiods 1972-1986, 1986-1999, and 1999-2011, the mean area loss rates were $8.5 \mathrm{~km}^{2} \mathrm{yr}^{-1}$ (equal to $118 \mathrm{~km}^{2}$ and $0.40 \mathrm{~km}^{2} \mathrm{yr}^{-1}$ glacier $\left.{ }^{-1}\right), 6.8 \mathrm{~km}^{2} \mathrm{yr}^{-1}\left(88 \mathrm{~km}^{2}\right.$ and $0.32 \mathrm{~km}^{2} \mathrm{yr}^{-1}$ glacier $\left.^{-1}\right)$, and $6.3 \mathrm{~km}^{2} \mathrm{yr}^{-1}\left(75 \mathrm{~km}^{2}\right.$ and $0.30 \mathrm{~km}^{2} \mathrm{yr}^{-1}$ glacier ${ }^{-1}$ ), respectively (Fig. 6), indicating decreasing area loss rates since 1972 . This is probably because the side fjords to the Sermilik Fjord decreased in width the further up the fjord the marine-terminating moves. When looking at the mean GrIS outlet glaciers (Midgaard, Helheim, Tasis Sassik Fjord, Heims, and Fenris $(n=5))$ and the nonGrIS outlet glaciers $(n=16)$, they both had a mean trend towards lower annual area loss rates (Fig. 6); however, the absolute mean area loss rates were higher for the GrIS outlet glaciers. This suggests that outlet glaciers without deep beds are retreating far more slowly.

Box and Decker (2011) measured area change at 39 of the widest GrIS marine-terminating glaciers based on Moderate Resolution Imaging Spectroradiometer (MODIS) between 2000 and 2010, including the glaciers Midgaard, Helheim, and Fenris. Overall for the 39 glaciers, they exposed a cumulated net area of $1368 \mathrm{~km}^{2}$. On individual glacier scale, the observed area loss rates for the glaciers Midgaard, Helheim, and Fenris were $-2.9,-2.0$, and $-0.4 \mathrm{~km}^{2} \mathrm{yr}^{-1}$ for 1999-2011, respectively, compared to $-3.6,-2.5$, and $-0.3 \mathrm{~km}^{2} \mathrm{yr}^{-1}$ for 2000-2010 determined by Box and Decker (2011). The Landsat-derived area loss rates were in the same range as Box and Decker (2011) (97.5\% quartile), and both studies indicated that the clearest pattern of area exposure happened at the Midgaard Gletscher in the Sermilik 


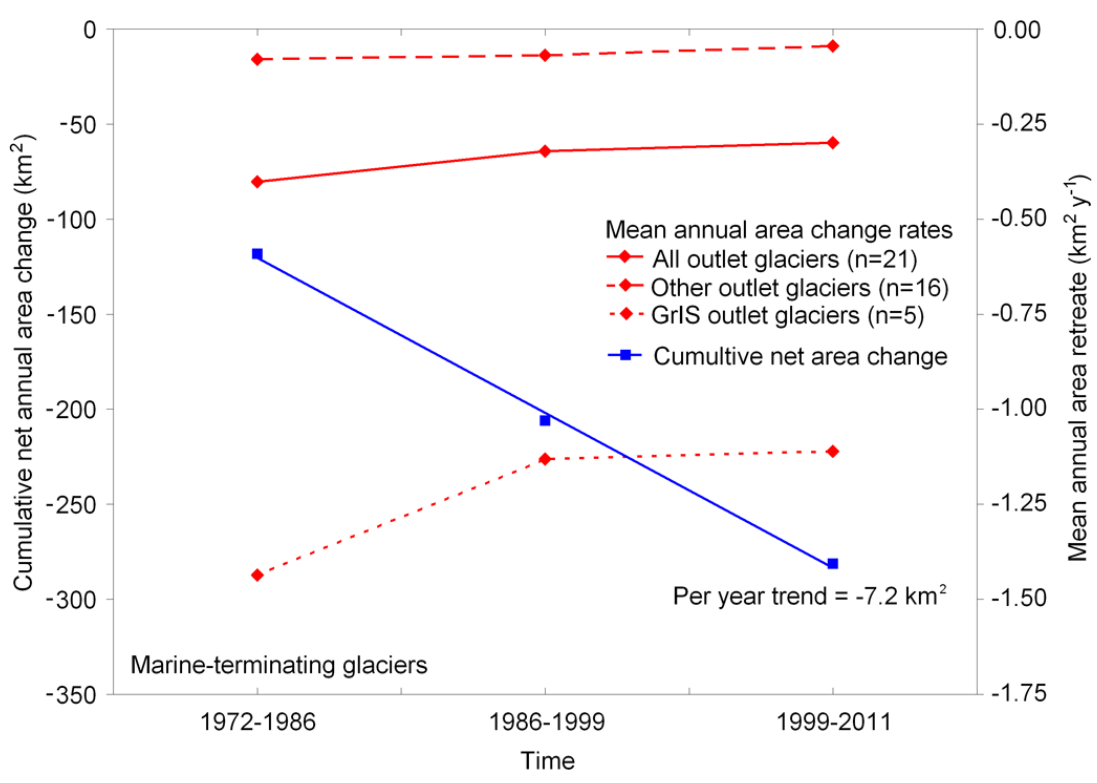

Fig. 6. Mean annual area change rates and cumulative net area change for all 21 marine-terminating glaciers, the five GrIS outlet glaciers, and other sixteen outlet glaciers for the Ammassalik region 1972-2011.

Fjord, even compared with the entire Southeast Greenland according to Box and Decker (2011).

Several authors (e.g., Holland et al., 2008; Murray et al., 2010; Straneo et al., 2010; Andresen et al., 2011) suggest that ocean warming and warm subsurface waters caused large changes to submarine melting, marine-terminating glacier frontal positions and thinning, reduced resistive stress and ice discharge acceleration. In recent decades the 21 marineterminating glaciers in the Ammassalik region have experienced increasing frontal recession rates and decreasing area exposure rates that are synchronous with both increasing mean annual air temperature (MAAT) $\left(\sim 0.06^{\circ} \mathrm{C} \mathrm{yr}^{-1}\right.$, significant at $p<0.01$, where $p$ is level of significance) from the DMI meteorological station in Tasiilaq and reconstructed annual ocean water temperature $\left(\sim 0.12^{\circ} \mathrm{C} \mathrm{yr}^{-1}\right.$, significant $p<0.025$; at $400 \mathrm{~m}$ depth in the Irminger Sea penetrating into the Sermilik Fjord and exposing the lower part of glaciers such as Helheim and Fenris to warm waters with temperatures up to $4^{\circ} \mathrm{C}$; Johannessen et al., 2011) (Figs. 5b and 6). The mean glacier retreat was more widespread for 1999-2011 (approximately the first decade of the 21st century) than for the earlier sub-periods (1972-1986 and 19861999). The observed accelerated recession of the marineterminating glaciers in the Ammassalik region coincided with the onset of a warming trend in the sub-polar North Atlantic Ocean (Myers et al., 2007; Straneo et al., 2010), likely initiated by the influx of warmer deep water originating in the Irminger Sea (Holland et al., 2008; Hanna et al., 2009). This supports the hypothesis that ocean warming associated with shifts in the Irminger and East Greenland currents caused increasing submarine melt at the iceocean interface, and retreat, thinning, and acceleration as the loss of resistive stress at the terminus recedes (Joughin et al., 2010). However, oceanographic studies have demonstrated that although subtropical ocean waters reach glacial fjords in Southeast Greenland, there is no proof that they come into direct contact with glaciers (Walsh et al., 2012). Mechanisms driving the circulation of warmer North Atlantic waters are, however, still not well understood (e.g., Straneo et al., 2010). On the other hand, Johannessen et al. (2011) have argued (due to statistical correlation) that, based on annual frontal positions of Helheim Gletscher, $24 \%$ of the ice-front fluctuations could be accounted for by ocean temperatures and $56 \%$ by air temperatures, even though changes in frontal positions were influenced by a number of local factors, e.g., up-glacier ice dynamics and bed geometry. Overall, several studies using a range of different methods show that GrIS marine-terminating glaciers recede and mass loss might be influenced by atmospheric and probably more importantly by oceanographic impacts, especially in the southeastern part of the GrIS (Luthcke et al., 2006; Velicogna and Wahr, 2006; van den Broeke, 2009; Velicogna, 2009).

\subsection{The land-terminating ice sheet}

In Fig. 7 the GrIS land-terminating margin and changes within the Ammassalik region are illustrated for 1986, 1999, and 2011. Since 1986 the GrIS area has decreased in size within the Ammassalik region from $1166 \mathrm{~km}^{2}$ (1986), $1153 \mathrm{~km}^{2}$ (1999) to $1124 \mathrm{~km}^{2}$ (2011), indicating a net area loss of $4 \%$ (equal to an area exposure rate of $0.15 \% \mathrm{yr}^{-1}$ ) (Table 3). As such for the land-terminating GrIS, the area exposure rates were $1.0 \mathrm{~km}^{2} \mathrm{yr}^{-1}\left(13 \mathrm{~km}^{2}\right)$ and $2.4 \mathrm{~km}^{2} \mathrm{yr}^{-1}$ $\left(29 \mathrm{~km}^{2}\right)$ for the sub-periods 1986-1999 and 1999-2011, 


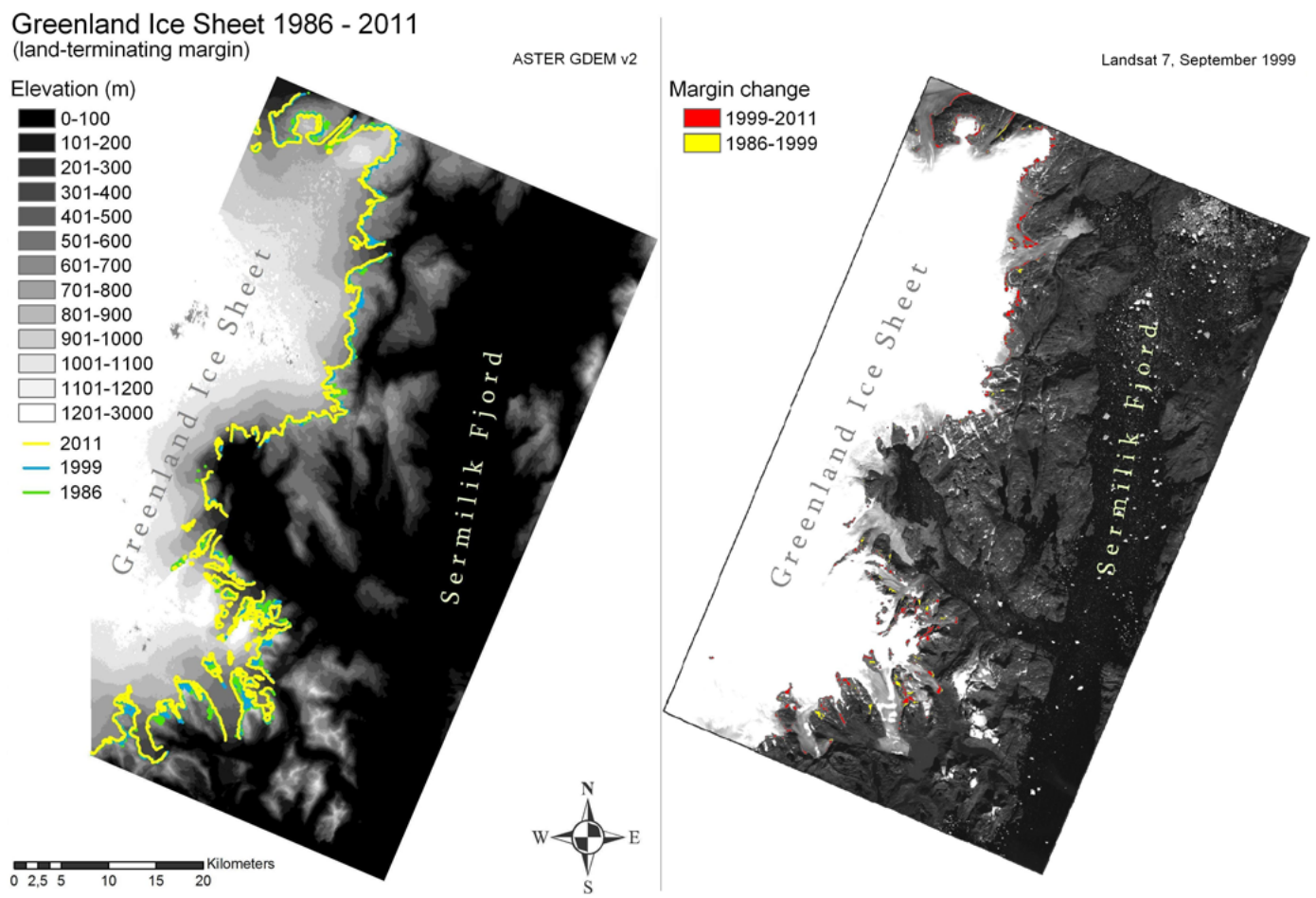

Fig. 7. The location of the GrIS land-terminating margin for the survey years 1986 (green), 1999 (blue), and 2011 (yellow) in the Ammassalik region, and the marginal changes between the survey years. The topography has black and gray shaded colors (source: ASTER GDEM v2 and Landsat 7).

Table 3. GrIS land-terminating margin-position change rate statistics for each survey year and period for the Ammassalik region.

\begin{tabular}{llll}
\hline Years & $\begin{array}{l}\text { GrIS margin length } \\
\text { for the highlighted } \\
\text { section in Ammassa- } \\
\text { lik region }(\mathrm{km})\end{array}$ & $\begin{array}{l}\text { GrIS area for the sec- } \\
\text { tion for the highlighted } \\
\text { section in Ammassalik } \\
\text { region }\left(\mathrm{km}^{2}\right)\end{array}$ & $\begin{array}{l}\text { Area in percentage } \\
\text { related to the 1986 } \\
\text { area }(\%)\end{array}$ \\
\hline 1986 & 686 & 1166 & 100 \\
1999 & 589 & 1153 & 99 \\
2011 & 544 & 1124 & 96 \\
\hline & GrIS mean margin & GrIS mean margin change $(\mathrm{km})$ & \\
& change rate $\left(\mathrm{km} \mathrm{yr}^{-1}\right)$ & & \\
\hline $1986-1999$ & -0.010 & -0.127 & \\
$1999-2011$ & -0.026 & -0.316 & \\
$1986-2011$ & -0.018 & &
\end{tabular}

respectively, indicating an increasing trend in area exposure since 1986. The land-terminating area exposure was unevenly distributed for the GrIS (Fig. 7). A division of the ice sheet into 100-m elevation bands indicated that the largest GrIS area recession occurred at the elevation between 701-800 $\mathrm{m}$ a.s.l. for both survey periods, with rates of $0.22 \mathrm{~km}^{2} \mathrm{yr}^{-1}$ (1986-1999) and $0.50 \mathrm{~km}^{2} \mathrm{yr}^{-1}$ (1999-2011) (Figs. 7 and 8). Along with this area reduction, the GrIS landterminating margin decreased $\sim 20 \%$ in total length from $686 \mathrm{~km}$ (1986) to $544 \mathrm{~km}$ (2011), because the 2011 margin was less curved - had fewer land-terminating outlets - than in 1986 and 1999. When the area recession is compared to changes in margin length, the largest GrIS area length recession ratio occurred at the elevation $>800 \mathrm{~m}$ a.s.l., most pronounced for the period 1999-2011 (Fig. 8). The spatial area recession seems to be highly influenced by local topography, hypsometry, shadow effects, climate variability, glacier dynamic processes within the GrIS, increasing ELA elevation (the ELA is the spatially averaged elevation of the equilibrium line, defined as the set of points on the glacier surface 


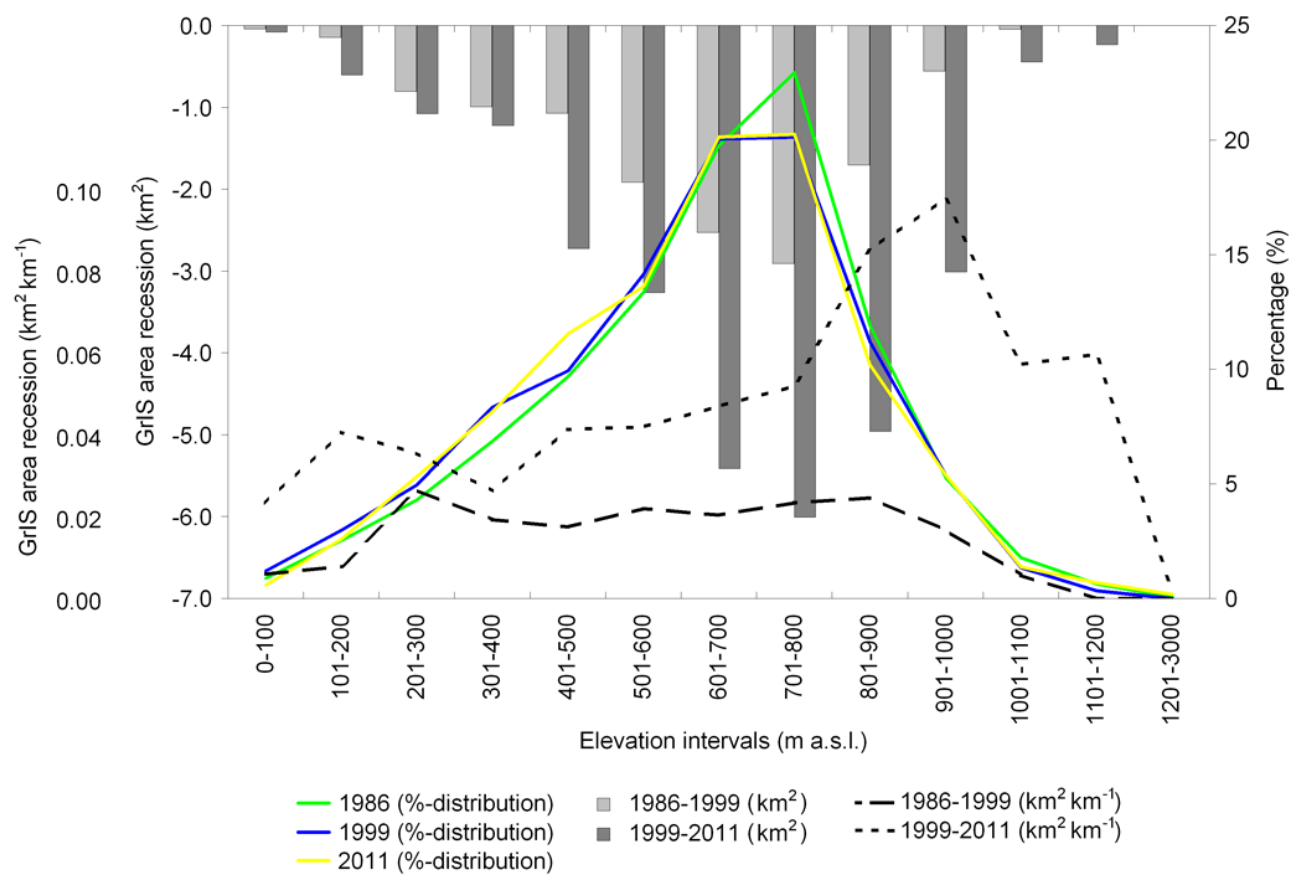

Fig. 8. GrIS land-terminating area recession rates for different elevation intervals, Ammassalik region, for the sub-periods 1986-1999 (light gray) and 1999-2011 (dark gray), area recession rate related to changes in margin length for 1986-1999 (black dashed line, long dashed) and 1999-2011 (black dashed line, short dashed), and the percentage of margin elevation for the different elevation intervals for the years 1986 (green), 1999 (blue), and 2011 (yellow) (see Fig. 7 for location of the margin).

where the net mass balance is zero), and the margin elevation distribution, where approximately $20 \%$ of the margin was located between 701-800 m a.s.l. (1986-2011) (Fig. 8).

The mean net recession rate of the GrIS land-terminating margin was $0.018 \pm 0.009 \mathrm{~km} \mathrm{yr}^{-1}$ (equal to a net recession of $0.443 \mathrm{~km}$ ) for 1986-2011, comprised of a mean recession rate of $0.010 \mathrm{~km} \mathrm{yr}^{-1}(0.127 \mathrm{~km})$ for $1986-1999$, and $0.026 \mathrm{~km} \mathrm{yr}^{-1}(0.316 \mathrm{~km})$ for 1999-2011 (Table 3). This land-terminating recession rate for the GrIS over this period of 1986-2011 is about three times lower the mean rate of recession of the marine-terminating GrIS. Sohn et al. (1998) measured recession rates of the GrIS landterminating margin near Jakobshavn Isbræ, West Greenland, of $0.016-0.040 \mathrm{~km} \mathrm{yr}^{-1}$, averaging $0.026 \mathrm{~km} \mathrm{yr}^{-1}$ for 1962 1992. This may suggest that the recession rate can be expected to be within this order of magnitude along many parts of the GrIS land-terminating margin.

Net GrIS land-terminating marginal recession for the Ammassalik region, including increasing area exposure, occurred for the period 1972-2011, during a period of increasing MAAT $\left(\sim 0.06^{\circ} \mathrm{C} \mathrm{yr}^{-1}\right)$ and decreasing annual precipitation $\left(-7.0 \mathrm{~mm}\right.$ water equivalent (w.e.) $\mathrm{yr}^{-1}$, significant at $p<0.025$; Fig. 5b) - probably heading towards future warmer and drier conditions in the region (Mernild et al., 2011a). The average increase in MAAT generally favors surface ablation (evaporation, sublimation, and melt), and an earlier start of the ablation season by decreasing the "cold content" of the snowpack (Bøggild et al., 2005; Mernild et al., 2011a), whereas a decrease in annual precipitation may lead to earlier exposure of glacier ice melt and summer firn surface of previous years (having a lower albedo than fresh snow, promoting increased solar absorption). Therefore, the combination of increasing air temperature and decreasing precipitation is likely to increase ablation and GrIS margin thinning and recession, and if MAAT and precipitation continue to follow these trends, then it is expected that the GrIS land-terminating margin will continue its recession, leading to increased area exposure. However, changes in the hypsometric distribution along the GrIS margin may influence recession rates on a decadal timescale.

\subsection{Land-terminating glaciers and ice caps}

Peripheral to the GrIS, 35 land-terminating GIC were chosen (Fig. 1) to assess area exposure for the Ammassalik region for 1986, 1999, and 2011 based on Landsat imagery. In Fig. 9 the size, mean elevation, and aspect distribution are illustrated for the $35 \mathrm{GIC}$, indicating that the majority of the GIC is below $5 \mathrm{~km}^{2}$, located between $400-800 \mathrm{~m}$ a.s.l., and facing south, west, and northwest. The GIC are non-surging glaciers located south of the East Greenland surge cluster (Jiskoot et al., 2003). For the Ammassalik region, the observed GIC indicated a relative mean area exposure of $4 \pm 18 \%$ for 19861999 , and $27 \pm 24 \%$ for $1986-2011$, which is equal to a mean net area exposure rate of $0.04 \mathrm{~km}^{2} \mathrm{yr}^{-1}$ per glacier 

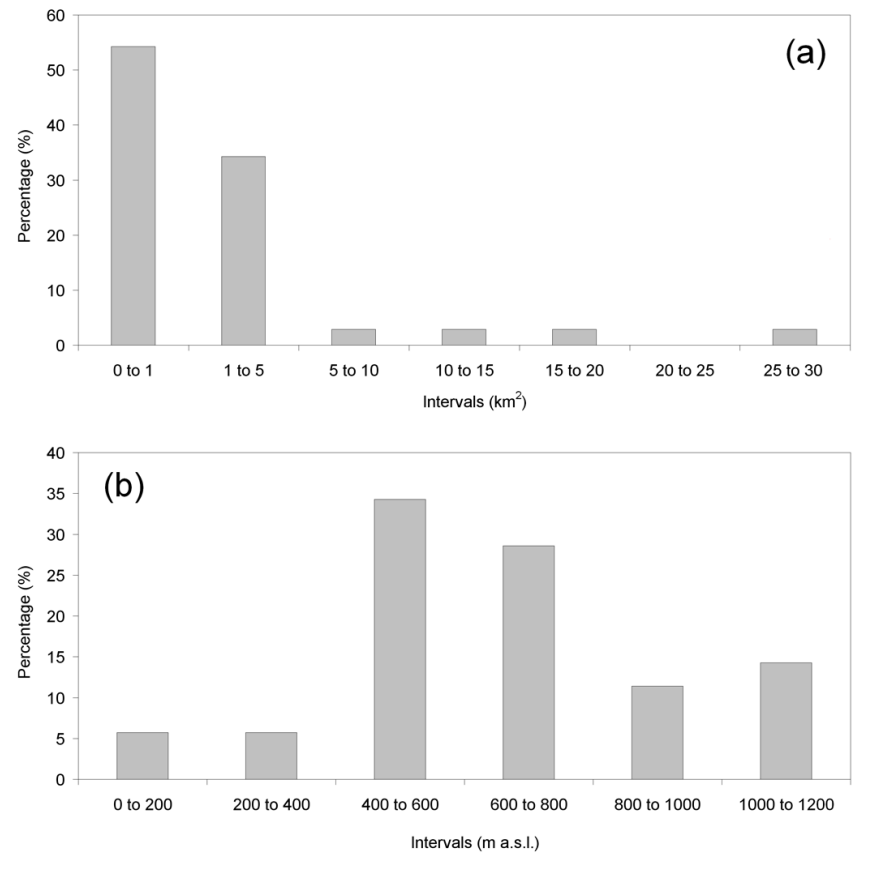

(c)

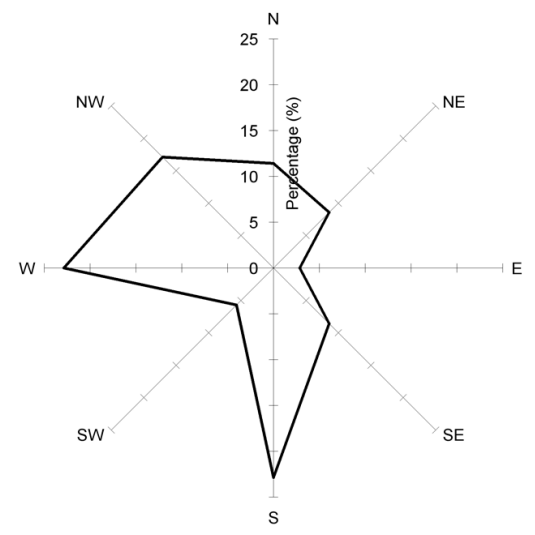

Fig. 9. Distribution of the 35 observed land-terminating GIC: (a) size; (b) mean elevation; and (c) aspect.

(or $1.07 \% \mathrm{yr}^{-1}$ per glacier) (Fig. 10a and b). For small GIC $\left(n=32 ;<10 \mathrm{~km}^{2}\right)$, the net area exposure rate was on average $1.08 \% \mathrm{yr}^{-1}$, and for large GIC $\left(n=3 ;>10 \mathrm{~km}^{2}\right)$ was a comparable rate of $0.81 \% \mathrm{yr}^{-1}$. For 1986-1999, eleven individual GIC (around $30 \%$, mostly below $2 \mathrm{~km}^{2}$ ) had a net increase in area, while for 1986-2011 there were only three GIC all facing towards the west (L11, L14, and L9; and around $10 \%$ - all less than $1 \mathrm{~km}^{2}$ ) (Fig. 10b). As illustrated in Fig. 10c, GIC having a mean elevation height higher than $705 \mathrm{~m}$ a.s.l. had in general a net area increase from 1986 to 1999 , while glaciers with a mean elevation lower than $705 \mathrm{~m}$ a.s.l. had a net area decrease (based on the significant linear regression; $r^{2}=0.38 ; p<0.01$ ). The height of $705 \mathrm{~m}$ a.s.l. was around the observed average ELA of $690 \mathrm{~m}$ a.s.l. at the Mittivakkat Gletscher in the late 1990s (Knudsen and Hasholt, 2004; Mernild et al., 2011a; Table 2).
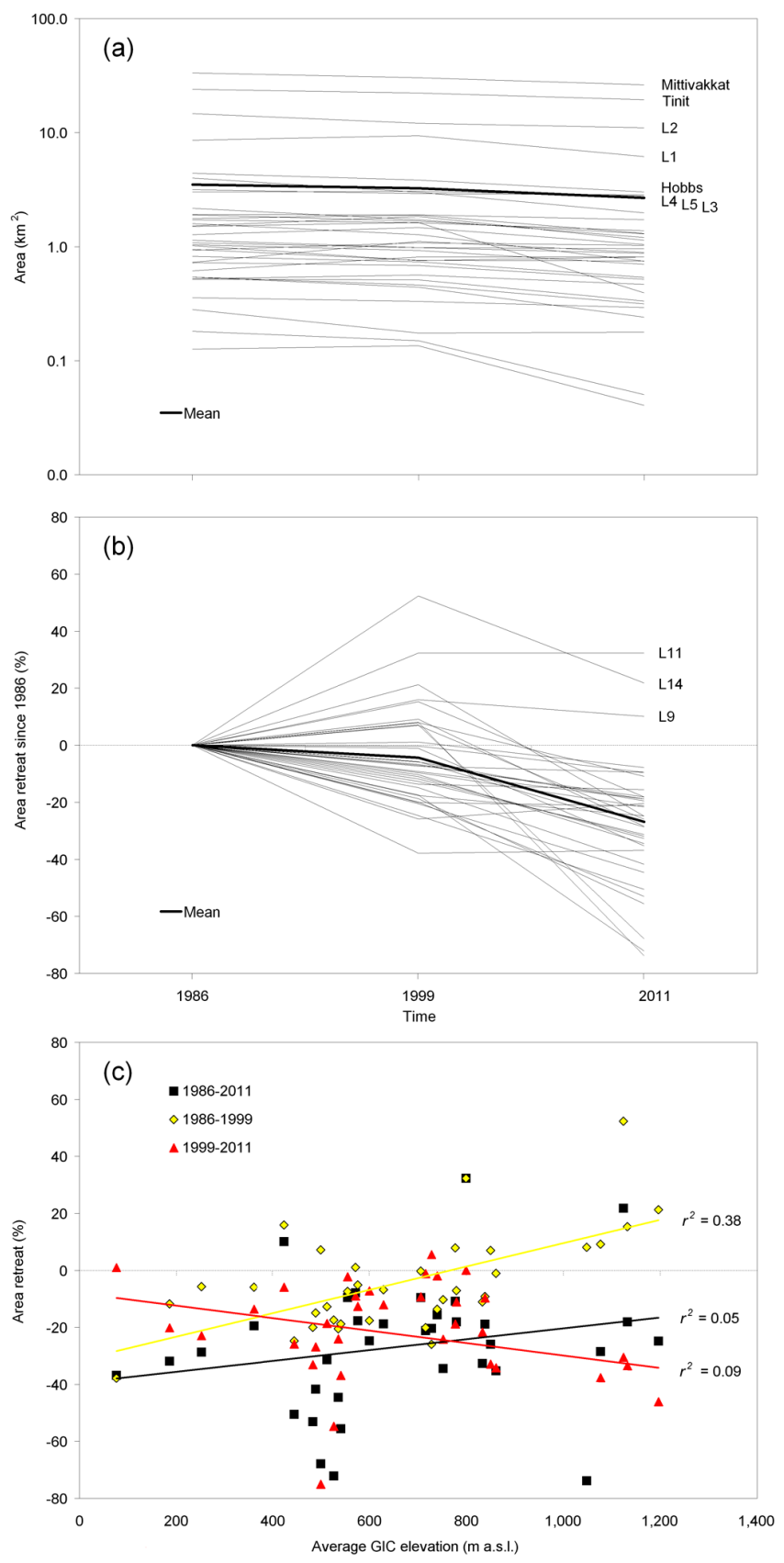

Fig. 10. (a) Land-terminating GIC area for the 35 observed GIC (Mittivakkat, Hobbs, Tinit, and L1-L32 glaciers) for 1986, 1999, and 2011 (the listed glaciers are illustrated as an example in Fig. 11); (b) relative GIC area change since 1986 (the named glaciers are the ones with area increase); and (c) relative GIC area change in relation to variations in mean elevation GIC height for 1986-1999, 1999-2011, and overall for 1986-2011.

For 1999-2011 the linear regression shown in Fig. 10c indicates the opposite trend for GIC in the Ammassalik region: an increase in area recession for GIC at high elevation ranges, and vice versa. This shift in trend occurred simultaneously with an increase in the average observed ELA for the 
Table 4. Characteristics of land-terminating GIC L33-L37 in the Ammassalik region, which have melted away during the period 1986-2011 (see Fig. 1 for location of the doomed glaciers).

\begin{tabular}{llllllll}
\hline GIC & $\begin{array}{l}\text { Minimum } \\
\text { elevation } \\
(m \text { a.s.1. })\end{array}$ & $\begin{array}{l}\text { Maximum } \\
\text { elevation } \\
\text { (ma.s.1. })\end{array}$ & $\begin{array}{l}\text { Mean elevation } \\
(\mathrm{m} \text { a.s.1. })\end{array}$ & Aspect & $\begin{array}{l}\text { Area } \\
1986 \\
\left(\mathrm{~km}^{2}\right)\end{array}$ & $\begin{array}{l}\text { Area } \\
1999 \\
\left(\mathrm{~km}^{2}\right)\end{array}$ & $\begin{array}{l}\text { Area } \\
\left(\mathrm{km}^{2}\right)\end{array}$ \\
\hline L33 & 507 & 792 & 634 & $\mathrm{E}$ & 0.178 & 0.050 & 0 \\
L34 & 462 & 538 & 513 & $\mathrm{E}$ & 0.041 & 0.034 & 0 \\
L35 & 846 & 910 & 893 & W & 0.036 & 0 & 0 \\
L36 & 777 & 896 & 841 & W & 0.076 & 0.016 & 0 \\
L37 & 1107 & 1145 & 1117 & SW & 0.018 & 0.029 & 0 \\
\hline
\end{tabular}

Mittivakkat Gletscher to $750 \mathrm{~m}$ a.s.1. Overall for 1986-2011, the observed GIC faced a general net area loss that was highest at low elevations, and vice versa (based on the linear regression; Fig. 10c). However, as previous mentioned, three minor GIC $\left(<1 \mathrm{~km}^{2}\right)$ had a net area gain during this $25-\mathrm{yr}$ period, indicating that glacier fluctuations may vary on local scales.

Since the GIC on average had a mean net area exposure rate of about $1 \% \mathrm{yr}^{-1}$, it may be expected that GIC in the Ammassalik region could melt substantially in the 21 st century under ongoing climate change. For the period 19862011, there are examples of five glaciers that completely melted away: all located at different mean elevations within the region from 460 to $1110 \mathrm{~m}$ a.s.l., and with different aspects facing from east to west (Table 4). The recession seems therefore not to be limited to low elevated areas only, but more likely to occur for north-facing GIC. Also, in Fig. 11, examples of eight GIC are shown to illustrate the spatial changes in margin location from 1986 to 2011.

For the largest GIC - the Mittivakkat Gletscher $\left(26.2 \mathrm{~km}^{2}\right.$ in 2011) - the area extent had diminished about $18 \%$ since 1986 (lower than the mean GIC area exposure for the Ammassalik region of $27 \pm 24 \%$ ). The terminus has retreated by $1.6 \mathrm{~km}\left(0.015 \mathrm{~km} \mathrm{yr}^{-1}\right)$ since the maximum extent of the Little Ice Age around 1900 , by $1.3 \mathrm{~km}\left(0.017 \mathrm{~km} \mathrm{yr}^{-1}\right)$ since 1931 (Humlum and Christiansen, 2008; Mernild et al., $2011 \mathrm{a})$, and by $0.3 \mathrm{~km}\left(0.013 \mathrm{~km} \mathrm{yr}^{-1}\right)$ since 1986 . This is almost of the same magnitude as the GIC of the Ammassalik region's mean net recession rate of $0.010 \pm$ $0.006 \mathrm{~km} \mathrm{yr}^{-1}$ (1986-2011), and of the regional GrIS landterminating margin of $0.018 \pm 0.009 \mathrm{~km} \mathrm{yr}^{-1}$ (see Sect. 3.2): the mean Ammassalik GIC land-terminating recession rate (1986-2011) is about five times lower than the mean GrIS marine-terminating recession rate. Also, for Mittivakkat Gletscher the annual mass balance measured continuously since 1995/1996 illustrates a 16-yr average mass loss of $0.970 \pm 0.190 \mathrm{mw}^{2}$.e. $\mathrm{yr}^{-1}$, and an accumulation-area ratio (AAR: the ratio of the accumulation area to the area of the entire glacier) of $\sim 0.10$ (updated from Mernild et al., 2011a), indicating that the glacier is significantly out of balance with the current climate. The glacier will likely lose at least $70 \%$ of its current area extent and $80 \%$ of its volume even in the absence of further climate changes (Mernild et al., 2011a). Since the initiation of the mass balance observation program in 1995/1996, Mittivakkat Gletscher had in 14 out of $16 \mathrm{yr}$ a negative surface mass balance, while the general climatic trend in the region has been towards higher temperatures, less winter precipitation, and more negative glacier mass balances and continuous marginal recession (Fig. 11). Consecutive record glacier mass loss occurred for the years 2009/2010 and $2010 / 2011$ of -2.16 and $-2.45 \mathrm{~m}$ w.e. $\mathrm{yr}^{-1}$, respectively. The 2011 mass loss was not only the largest annual loss of volume in the history of the mass balance observational program, but also the largest annual loss in simulations of glacier mass balance changes back to 1898 (Mernild et al., 2008). The marginal recession, mass balance and AAR observations suggest that recent Mittivakkat mass losses, which have been driven largely by higher surface temperatures and less solid precipitation, are representative of the broader region, which includes the 35 observed GIC in Figs. 10 and 11 - glaciers of different sizes and elevation ranges. This is confirmed since the Mittivakkat Gletscher net area exposure rate closely follows the average rates for the Ammassalik region.

Glacier fluctuations and area exposure have been studied in other parts of Greenland. North of the Ammassalik region, in central East Greenland $\left(68-72^{\circ} \mathrm{N}\right)$ land-terminating GIC peripheral to the GrIS have receded at a mean rate of $0.010 \mathrm{~km} \mathrm{yr}^{-1}$ for a wide range of glacier sizes (2002-2009) (Kargel et al., 2012). Also, on Disko Island in West Greenland, Yde and Knudsen (2007) estimated mean GIC terminus retreat rates of $0.008 \mathrm{~km} \mathrm{yr}^{-1}$ for non-surging GIC, and $0.020 \mathrm{~km} \mathrm{yr}^{-1}$ for quiescent phase surge-type GIC, reflecting a higher non-climatic-driven recession rate after glacier surges. These studies are in accordance with the findings for the Ammassalik region and indicate that the current mean recession rate for GIC in Greenland (probably excluding North Greenland where no data are currently available) is likely to be on the order of $0.008-0.010 \mathrm{~km} \mathrm{yr}^{-1}$.

\section{Summary and conclusion}

The satellite observations show net glacier recession since 1972 for the Ammassalik region for all glacier types and sizes, both at the marine-terminating and land-terminating 


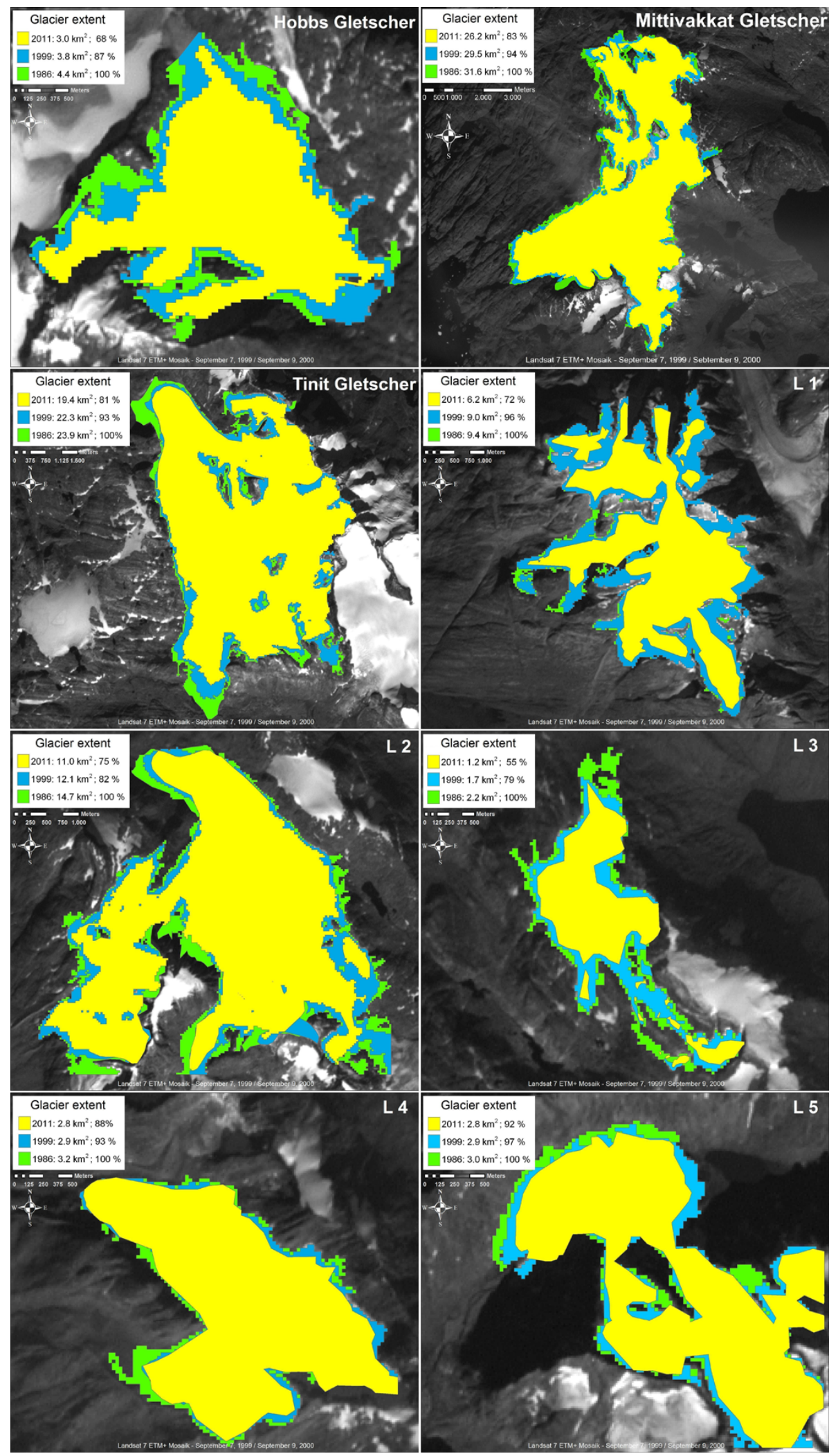

Fig. 11. The margin location of eight land-terminating GIC (peripheral to the GrIS) in the Ammassalik region: Hobbs, Mittivakkat, Tinit, and L1-L5 glaciers for the survey years 1986 (green), 1999 (blue), and 2011 (yellow) estimated from Landsat images. The location of the individual glaciers is shown in Fig. 1 (source: Landsat 7 ETM+ Mosaik, 7 September 1999/9 September 2000). 
GrIS, and land-terminating GIC. However, the landterminating GrIS and GIC reflect slower area exposure rates than the faster marine-terminating outlet glaciers. This could likely be due to a combination of effects, as the marineterminating GrIS was influenced by the onset of a sea-water warming trend in the North Atlantic Ocean (Myers et al., 2007; Straneo et al., 2010), and by atmospheric impacts from regional trends in MAAT and precipitation, while GIC were only influenced by the latter. For the marine-terminating GrIS outlet glaciers the mean annual area exposure rate has decreased since 1972, whereas it has increased for the landterminating GrIS margin since 1986, even though both parts of the GrIS have undergone substantial area changes in the past decades. The observed land-terminating GrIS and GIC indicate a net area recession of $4 \%$ (equal to an area exposure rate of $0.15 \% \mathrm{yr}^{-1}$ ) and $27 \pm 24 \%$ (around $1 \% \mathrm{yr}^{-1}$ ), respectively, and margin recession rates of $0.018 \pm 0.009$ and $0.010 \pm 0.006 \mathrm{~km} \mathrm{yr}^{-1}$. These mean net margin recession rates are about three to five times lower than the GrIS marineterminating margin rates. If these GIC recession trends were extrapolated, it would indicate that a substantial amount of the GIC in the Ammassalik region might melt away within the 21 st century under ongoing climate warming. So far, five GIC in the Ammassalik region have melted away since 1986.

Acknowledgements. The authors thank Matthew Hecht, Mauri Pelto, and the anonymous reviewers for their insightful review of this paper. We also thank Ola M. Johannessen for providing the reconstructed ocean water data. This work was partly supported by the Earth System Modeling program and by the Scientific Discovery for Advanced Computing (SciDAC) program within the US Department of Energy's Office of Science and by a Los Alamos National Laboratory (LANL) Director's Fellowship. LANL is operated under the auspices of the National Nuclear Security Administration of the US Department of Energy under Contract No. DE-AC52-06NA25396), and partly from the European Community's Seventh Framework Programme under grant agreement No. 262693. S. H. M. and J. K. M. compiled the satellite images, analyzed the data, and wrote the manuscript. J. C. Y. and N. T. K. contributed to the discussion of results and writing of the text.

Edited by: E. Hanna

\section{References}

Andresen, C. S., Straneo, F., Riebergaard, M. H., Bjørk, A. A., Andersen, T. J., Kuijpers, A., Nørgaard-Pedersen, N., Kjær, K. H., Schjøth, F., Weckstrom, K., and Ahlstrøm A. P.: Rapid response of Helheim Glacier in Greenland to climate variability over the past century, Nat. Geosci., 5, 37-41, doi:10.1038/NGEO1349, 2011.

Box, J. E. and Decker, D. T.: Greenland marine-terminating glacier area changes: 2000-2010, Ann. Glaciol., 52, 91-98, 2011.

Bøggild, C. E., Forsberg, R., and Reeh, N.: Melt: Water in a transect across the Greenland ice sheet, Ann. Glaciol., 40, 169-173, 2005.
Dozier, J. and Warren, S. G.: Effect of viewing Angle on the Infrared Brightness Temperature of Snow, Water Resour. Res., 18, 1424 1434, 1982.

Earth Observing System Data and Information System (EOSDIS): Earth Observing System ClearingHOuse (ECHO)/Warehouse Inventory Search Tool (WIST) Version 10.X. Greenbelt, MD: EOSDIS, Goddard Space Flight Center (GSFC) NASA, 2009.

Gao, B.-C.: NDWI - A Normalized Difference Water Index for Remote Sensing of Vegetation Liquid Water From Space, Remote Sens. Environ., 58, 257-266, 1996.

Hanna, E., Cappelen, J., Fettweis, X., Huybrechts, P., Luckman, A., and Ribergaard, M. H.: Hydrologic response of the Greenland ice sheet: the role of oceanographic warming, Hydrol. Process., 23, 7-30, 2009.

Holland, D. M., Thomas, R. H., de Young, B., Ribergaard, M. H., and Lyberth, B.: Acceleration of Jakobshavn Isbrae triggered by warm subsurface ocean waters, Nat. Geosci., 1, 659-662, 2008.

Howat, I. M. and Eddy, A.: Multi-decadal retreat of Greenland's marine-terminating glaciers, J. Glaciol., 57, 389-396, 2011.

Howat, I. M., Joughin, I., Tulaczyk, S., and Gogineni, S.: Rapid retreat and acceleration of Helheim Glacier, East Greenland, Geophys. Res. Lett., 32, L22502, doi:10.1029/2005GL024737, 2005.

Howat, I. M., Joughin, I., and Scambos, T. A.: Rapid Changes in Ice Discharge from Greenland Outlet Glaciers, Science, 315, 15591561, 2007.

Howat, I. M., Joughin, I., Fahnestock, M., Smith, B. E., and Scambos, T.: Synchronous retreat and acceleration of southeast Greenland outlet glaciers 2000-2006: ice dynamic and coupling to climate, J. Glaciol., 54, 646-660, 2008.

Humlum, O. and Christiansen, H. H.: Geomorphology of the Ammassalik Island, SE Greenland, Geogr. Tidssk., 108, 5-20, 2008.

Jiskoot, H., Murray, T., and Luckman, A.: Surge potential and drainage-basin characteristics in East Greenland, Ann. Glaciol., 36, 142-148, 2003.

Johannessen, O. M., Korablev, A., Miles, V., Miles, M. W., and Solberg, K. E.: Interaction Between the Warm Subsurface Atlantic Water in the Sermilik Fjord and Helheim Glacier in Southeast Greenland, Surv. Geophys, 32, 387-396, doi:10.1007/s10712011-9130-6, 2011.

Joughin, I., Abdalati, W., and Fahnestock, M. A.: Large fluctuations in speed on Greenland's Jakobshavn Isbrae glacier, Nature, 432, 608-610, 2004.

Joughin, I., Smith, B. E., Howat, I. M., Scambos, T., and Moon, T.: Greenland Flow variability from ice-sheet-wide velocity mapping, J. Glaciol., 56, 415-430, 2010.

Knudsen, N. T. and Hasholt, B.: Mass balance observations at Mittivakkat Glacier, southeast Greenland 1995-2002, Nord. Hydrol., 35, 381-390, 2004.

Kargel, J. S., Ahlstrøm, A. P., Alley, R. B., Bamber, J. L., Benham, T. J., Box, J. E., Chen, C., Christoffersen, P., Citterio, M., Cogley, J. G., Jiskoot, H., Leonard, G. J., Morin, P., Scambos, T., Sheldon, T., and Willis, I.: Brief communication Greenland's shrinking ice cover: "fast times" but not that fast, The Cryosphere, 6, 533-537, doi:10.5194/tc-6-533-2012, 2012.

Luthcke, S., Zwally, H. J., Abdalati, W., Rowlands, D. D., Ray, R. D., Nerem, R. S., Lemoine, F. G., McCarthy, J. J., and Chinn, D. S.: Recent Greenland mass loss by drainage system from satellite gravity observations, Science, 314, 1286-1289, 2006. 
Mernild, S. H., Kane, D. L., Hansen, B. U., Jakobsen, B. H., Hasholt, B., and Knudsen, N. T.: Climate, glacier mass balance, and runoff (1993-2005) for the Mittivakkat Glacier catchment, Ammassalik Island, SE Greenland, and in a long term perspective (1898-1993), Hydrol. Res., 39, 239-256, 2008.

Mernild, S. H., Knudsen, N. T., Lipscomb, W. H., Yde, J. C., Malmros, J. K., Hasholt, B., and Jakobsen, B. H.: Increasing mass loss from Greenland's Mittivakkat Gletscher, The Cryosphere, 5, 341-348, doi:10.5194/tc-5-341-2011, 2011a.

Mernild, S. H., Mote, T., and Liston, G. E.: Greenland Ice Sheet surface melt extent and trends, 1960-2010, J. Glaciol., 57, 621628, 2011b.

Mernild, S. H., Hanna, E., Knudsen, N. T., Yde, J. C., and Seidenkrantz, M.-S.: The climate impact on observed land terminating glaciers and ice caps in Northern North Atlantic, J. Climate, in review, 2012.

Moon, T. K. and Joughin, I.: Retreat and advance of Greenland tidewater glaciers from 1992 to 2007, J. Geophys. Res., 113, F02022, doi:10.1029/2007JF000927, 2008.

Myers, P., Kulan, N., and Ribergaard, M. H.: Irminger Water variability in the West Greenland Current, Geophys. Res. Lett., 34, L17601, doi:10.1029/2007GL030419, 2007.

Murray, T., Scharrer, K., James, T. D., Dye, S. R., Hanna, E., Booth, A. D., Selmes, N., Luckman, A., Hughes, A. L. C., Cook, S., and Huybrechts, P.: Ocean regulation hypothesis for glacier dynamics in southeast Greenland and implications for ice sheet mass changes, J. Geophys. Res., 115, F03026, doi:10.1029/2009JF001522, 2010.

Nick, F., Vieli, M. A., Howat, I. M., and Joughin, I.: Large-scale changes in Greenland outlet glacier dynamics trigged at the terminus, Nat. Geosci., 2, 110-114, doi:10.1038/NGEO394, 2009.

Paul, F.: The New Swiss Glacier Inventory 2000 - Application of remote sensing and GIS, Ph.D. thesis, Department of Geography, University of Zurich, 198 pp., 2004.

Radić, V. and Hock, R.: Regionally differentiated contribution of mountain glaciers and ice caps to future sea-level rise, Nat. Geosci., 4, 91-94, 2011.

Rignot, E. and Kanagaratnam, P.: Changes in the velocity structure of the Greenland Ice Sheet, Science, 311, 986-990, 2006.

Rignot E., Knoppes, M., and Velicogna, I.: Rapid submarine melting of the calving faces of West Greenland glaciers, Nat. Geosci., 3, 187-191, 2010.

Rouse, J. W., Haas, R. H., Schell, J. A., and Deering, D. W.: Monitoring vegetation systems in the Great Plains with ERTS, Third ERTS Symposium, NASA SP-351, I, 309-317, 1973.
Sohn, H.-G., Jezek, K. C., and van der Veen, C. J.: Jakobshavn Glacier, West Greenland: 30 years of spaceborne observations, Geophys. Res. Lett., 25, 2699-2702, 1998.

Straneo, F., Hamilton, G. S., Sutherland, D. A., Sterns, L. A., Davidson, F., Hammill, M. O., Stenson, G. B., and Rosing-Asvid, A.: Rapid circulation of warm subtropical waters in a major glacial fjord in East Greenland, Nat. Geosci., 3, 182-222, 2010.

Tachikawa, T., Kaku, M., Iwasaki, A., Gesch, D., Oimoen, M., Zhang, Z., Danielson, J., Krieger, T., Curtis, B., Haase, J., Abrams, M., Crippen, R., and Carabajal, C.: ASTER Global Digital Elevation Model Version 2 - Summary of Validation Results, NASA Land Processes Distributed Active Archive Center and the Joint Japan-US ASTER Science Team (https://igskmncnwb001.cr.usgs.gov/aster/GDEM/ Summary_GDEM2_validation_report_final.pdf), 2011.

Thomas, R., Frederick, E., Krabill, W., Manizade, S., and Martin, C.: Recent changes on Greenland outlet glaciers, J. Glaciol., 55, 147-162, 2009.

Truffer, M. and Fahnestock, M.: Rethinking ice sheet time scales, Science, 315, 1508-1510, 2007.

van den Broeke, M., Bamber, J., Ettema, J., Rignot, E., Schrama, E., van de Berg, W., van Meijgaard, E., Velicogna, I., and Wouters, B.: Partitioning Recent Greenland Mass Loss, Science, 326, $984-$ 986, 2009.

Velicogna, I.: Increasing rates of ice mass loss from the Greenland and Antarctic ice sheets revealed by GRACE, Geophys. Res. Lett., 36, L19503, doi:10.1029/2009GL040222, 2009.

Velicogna, I. and Wahr, J.: Acceleration of Greenland ice mass loss in spring 2004, Nature, 443, 329-331, 2006.

Walsh, K. M., Howat, I. M., Ahn, Y., and Enderlin, E. M.: Changes in the marine-terminating glaciers of central east Greenland, 2000-2010, The Cryosphere, 6, 211-220, doi:10.5194/tc-6-2112012, 2012.

WGMS: Glacier Mass Balance Bulletin, Bulletin No. 10 (2006-2007), edited by: Haeberli, W., GartnerRoer, I., Hoelzle, M., Paul, F., and Zemp, M., ICSU(WDS)/IUGG(IACS)/UNEP/UNESCO/WMO, World Glacier Monitoring Service, Zurich, 96 pp., 2009.

Yde, J. C. and Knudsen, N. T.: 20th-century glacier fluctuation on Disko Island (Qeqertarsuaq), Greenland, Ann. Glaciol., 46, 209214, 2007. 